\title{
CLUES FOR MINAEAN HISTORY. \\ A CHRONOLOGICAL REASSESSMENT IN LIGHT OF NEW EPIGRAPHIC AND ARCHAEOLOGICAL DATA FROM BARĀQISH $\left(5^{\mathrm{TH}}\right.$ AND $4{ }^{\mathrm{TH}}$ CENTURIES BC)
}

\begin{abstract}
Alessio Agostini - Sapienza University of Rome
A considerable amount of new data, both archaeological and epigraphic, were discovered during the Italian excavations at the site of Barāqish (ancient Minaean Yathil). The present paper discusses the most relevant additions to our knowledge base as a result of those excavations, particularly in relation to the succession of kings in Ma in during the $5^{\text {th }}$ and $4^{\text {th }}$ centuries $B C$. At this time, the kingdom arrived at its apogee under the reigns of Abiyada 'Yatha' and his son, Waqih 'il Riyäm.

The findings rely on new radiometric analyses and fresh epigraphic documents, concerning sectors of the temple Qabdum and the area external to the southern urban walls. Improvements are made to the relative sequencing and absolute dating of kings, with the support of recent methodological contributions to the scholarly literature.
\end{abstract}

Keywords: Ancient South Arabia; Ma'īn; Barāqish; epigraphy; chronology

\section{INTRODUCTION}

Although the general historical framework of the Minaean kingdom has emerged more clearly over the past decades, there remain many shortcomings relating to specific historical points; for example, our understanding of the succession of Minaean kings presents several issues and is certainly open to further scrutiny. The Minaean site of Yathil (present day Barāqish, in the Jawf region), with its vast epigraphic documentation, represents a primary source of data for the history of this South Arabian kingdom (fig. 1). In the 1990s and 2000s, new findings were produced because of various investigations in several sectors of the site by the Italian Archaeological Mission to the Republic of Yemen (MAIRY). The present paper presents a synthetic overview of some of the most significant results, pertaining to the chronology of Ma'in, especially during the $5^{\text {th }}$ and $4^{\text {th }}$ centuries $\mathrm{BC} .^{1}$ In particular, the excavations resulted in improvements to both the relative sequencing and absolute dating of Minaean kings at this time, with the support of a new radiometric analysis. The findings offer some significant historical data relating to the Minaean dynastic succession. ${ }^{2}$ The most relevant material was produced from the excavations of the

1 The general archaeological report of the last campaigns to Barāqish is ready to go to press with the provisional title Barāqish/Yathill. Excavations of the 'Athtar dhu-Qabd temple and extramural areas and is edited by Sabina Antonini and Francesco G. Fedele. The present author was entrusted with studying the epigraphic documentation coming from several sectors of the site (sacral area and urban walls), as well as analyzing the archaeological data from the temple of 'Athtar dhu-Qabḍ. The study was conducted in collaboration with Sabina Antonini and Vittoria Buffa, who studied the artifacts and pottery, respectively. Francesco G. Fedele kindly provided useful advice on chronological issues and was invaluable for the radiometric analyses. The present author is deeply grateful to A. de Maigret and S. Antonini for allowing him the opportunity to study these important materials.

2 All inscriptions are organized in tab. 1 and are cited according to the open Digital Archive for the Study of Pre-Islamic Arabian Inscriptions - DASI (http://dasi.cnr.it/), where further details and a bibliography can be

ISSN 0393-0300

e-ISSN 2532-5159

Rivista Open Access 
temple Qabdum ${ }^{3}$ and a small external area close to the southern urban walls. The present discussion is consequently limited to these sectors.

\section{A 14C DATING FOR THE TEMPLE QABDUM}

The intra-muros campaigns in Barāqish between 2004 and 2006 concentrated on the sacral area, focusing on the temple Qabdum (Temple B) - dedicated to the Minaean god 'Athtar dhu-Qabḍ - following the excavations in the 1990s of the adjacent temple Barān (Temple A) - dedicated to the god Nakrah (fig. 1). ${ }^{4}$ During this work, Qabdum's hypostyle hall and propylaeum were entirely unearthed, exposing a monumental building that was occupied by the Minaeans until the end of the $1^{\text {st }}$ century BC. The temple was later used as a sacral monument by the Amīr - an intrusive group that briefly installed on the site until sometime between the $1^{\text {st }}$ and $2^{\text {nd }}$ centuries $\mathrm{AD} \mathrm{ca}$. The excavations documented three intense Islamic phases (Ancient, Middle, and Recent), which revived the area after a long period of abandonment and a partial spoliation. These episodes seem to have affected the underlying archaeological context of both temples (Qabḍum and Barān), though with differing intensity. A general assessment of the archaeological results from the temple Qabdum is beyond the scope of the present paper, ${ }^{5}$ but it may be useful to convey that this imposing building is characterized by a large internal quadrangular hall (each side approximately $13 \mathrm{~m}$ ) sustained by 12 pillars and organized into 4 lateral cenacles, with 2 on each side; these are divided by a central corridor that leads to a slightly raised longitudinal transept. ${ }^{6}$ In this area, just opposite the entrance, the central cella also opens, with two large rooms on each lateral side; these were originally closed and probably used as sacraria. The temple Qabdum is an example of a Minaean intra-muros hypostyle temple, even though the possible presence of an upper story is unprecedented in this tradition. ${ }^{7}$

In the internal transept - precisely towards the southeastern limit (i.e. locus L110, near wall M118) - a piece of burnt wood (siglum Bar.05.B/2a) was recovered on the surface of the floor at the Minaean level. This was the only specimen considered suitable for radiometric analysis, because it pertained - with certainty - to the Minaean phase of the preIslamic temple. While it may have originated from an unidentified movable wood furniture item, it was more likely part of the door of the southern sacrarium, which was accessible through this exact portion of the hall. Judging from the thickness of the remaining door jambs, the door was likely quite heavy. The wood charcoal was collected on 29 December 2005 and later submitted to the CIRCE laboratory. ${ }^{8}$ The result was communicated to

found. Vocalization of proper names follows the usual conventions, which do not necessarily reflect the original South Arabian forms.

Agostini 2015; see also fn. 1.

de Maigret - Robin 1993; de Maigret 2009

A preliminary notice is in de Maigret 2009 and Agostini 2015.

Agostini 2020.

Jung 1989; Schmidt 1997

Center for Isotopic Research on Cultural and Environmental Heritage, supported by the Innova consortium and the Department of Environmental Sciences (Second University of Naples, now Università degli Studi della Campania 'Luigi Vanvitelli', Caserta). Further dating, as well as a re-assessment of previous analyses from the temple of Nakrah, will be provided by Francesco G. Fedele in the forthcoming general archaeological report (cf. fn. 1); see also below. 
Alessandro de Maigret, then director of the MAIRY, who was unable to work on the specimen immediately. After de Maigret's passing, the datum remained unnoticed in his archive and was only recovered once the complete documentation from the campaign was reassessed during work on the general field report.

The result of the charcoal analysis is as follows:

Bar.05.B/2a | DSH-375 | $2438 \pm 27$ | preliminary calibration 750-687, 593-406 BC Probability for dating to the $6^{\text {th }}-5^{\text {th }}$ century BC $70 \%$.

This calculation is of major importance because of the archaeological context in which it was found, and it deserves to be considered within the history of the temple's foundation. According to this result, we can infer that the piece originated from the ancient phase of the temple, pertaining to the previous Minaean frequentation. This is probably because it was part of an internal fixed element that remained undisturbed, even during the passage of the Amīr tribe, which occupied the temple around the $1^{\text {st }}$ century BC/AD. ${ }^{9}$

On the other hand, this datum is limited by the weakness of the single measurement. A radiometric analysis cannot be considered alone, as it rarely provides a clear absolute dating within a precise interval. Nonetheless, when considered in light of epigraphic evidence, it may be extremely valuable in directing and specifying a chronological issue.

\section{EPIGRAPHIC DATA RELATING TO THE FOUNDATION OF THE TEMPLE QABDUM}

The Minaic epigraphic documentation from the temple Qabdum is rather clear, as far as the foundation of the building is concerned, and it can be combined with the archaeological datum. ${ }^{10}$ Inscription Y.05.B.B.13 was found inside the hypostyle hall and recalls that the temple was realized "from foundation to the top" ( $b n$ ' $s^{2} r s^{I} m$ ' $d s^{2} q r n$ ) by Ya'ws'il, son of Yisma 'il dhu-Ġazīr Saḥfān, under the auspices of the Minaean King Waqih'il Riyām. The text is engraved on a panel that had collapsed on its back side in the transept - not far from the source of the charcoal sample - but was originally used to screen off the transept from the southern cenacles. It was initially believed to be the upper part of a smooth anepigraphic slab that remained in place in the same nave. Although the inscribed slab was broken in several pieces, the text was easily recomposed. At the time the slab fell, the area was already covered by several centimeters of sandy deposit; thus, the structure had already been abandoned for some time. Another inscribed panel was found in situ in the southern nave, contiguous to the nave in which the previous panel was found. This second inscription (Y.05.B.B.12) appeared to be the second part of an inscription that began on an upper vertical slab that was apparently no longer in place (fig. 2). The text concludes with the commitment of the dedications and inscriptions $\left(s^{3} l^{3}-s^{1} w-s^{1} t r-s^{l}\right)$ to the gods and kings of Ma'in, with the usual formula used to celebrate the conclusion of construction works.

9 During the crisis of the Minaean realm at the end of the $1^{\text {st }}$ millennium BC, some parts of the southern Jawf were occupied by scattered groups of diverse origin. Among these were the Amīr, who probably originated in the Najrān region (Agostini 2018). At the same time, late post-Minaean levels do not show any significant variation in pottery shapes and techniques.

10 The following is an update of the discussion in Agostini (2011). 
The author is the same Ya'ws'il, son of Yisma 'il dhu-Ġazīr Sạ̣fān, and the King Waqih'il Riyām is again remembered, but here in a coregency with his son Aws'il, who seems to have never succeeded him - at least not with this name (see below). The two inscriptions can be considered in strict succession, if not collated, as they describe consecutive moments: the commitment of the temple's works under Waqih'il Riyām and the completion and inauguration of the temple in a later phase of Waqih'il Riyām's reign, when he was associated with a coregent. ${ }^{11}$

Although isolated, the radiometric datum from the temple Qabdum is indirectly supported by a couple of earlier radiometric datings from charcoals collected from the neighboring temple Barān during excavations in the 1990s. We know from written documents that the temple Barān pre-existed the temple Qabḍm, as it already had some refurbishments at the time of King Abìyada' Yatha', father of Waqih'il Riyām. ${ }^{12}$ These interventions may be tentatively connected with the Minaean phase B of the temple Barān, which was dated to 590-380 BC, 82\% probability (based on sample Y.92.B./138), while the most ancient Minaean phase $\mathrm{C}$ was dated to $800-510 \mathrm{BC}$, 99\% probability (sample Y.92.B./135). ${ }^{13}$

\section{DATING OF KING WAQIH’IL RIYĀM}

The excavations of the temple of 'Athtar dhu-Qabd provided the first independent archaeologically-based dating for King Waqih'il Riyām, whose chronological positioning had previously been inferred from an interpretation of the so-called "Persian-Minaean synchronism." This highly controversial external connection was recorded during the reign of King Waqih'il Riyām's father, King Abīyada' Yatha', and it is dated to the mid-4 $4^{\text {th }}$ century BC by the majority of scholars (RES 3022, see below). In the following, we discuss the new archaeological datum and consider whether it can clarify the dating of King Waqih'il Riyām.

As previously stated, the calibrated radiometric result of a date between the $6^{\text {th }}$ and $5^{\text {th }}$ centuries $\mathrm{BC}$ indicates that the sample belonged to a piece of finishing that was original to the temple and remained there until its dismission/abandonment. Its discovery on the floor may be a consequence of a fall following deterioration and burning, which further excludes the possibility of an attribution to the final phase of the temple. However, it would be wise

11 The possibility of a collation of fragments Y.05.B.B.13 and Y.05.B.B.12 cannot be excluded, but was initially ruled out due to their discovery sites: Y.05.B.B.13 appeared to have been originally placed in the nave contiguous to that in which Y.05.B.B.12 still stood. There are fairly good arguments to support a reciprocal collation: the phrasing at the end of Y.05.B.B.13 does not contrast with the beginning of Y.05.B.B.12; the two slabs are not identical in width, but the difference is marginal; moreover, Y.05.B.B.13 mentions the king alone, whereas Y.05.B.B.12 refers to him in coregency with his son: this does not necessarily suggest that slab Y.05.B.B.12 is younger, as some Minaic texts omit coregency, though indicate it in different passages of the same inscription; this could also be intentional, as a reference to different temporal circumstances (cf. RES 2771: 'lyf' Rym w-bn-s ${ }^{\prime} H w f^{\prime} \underline{t} t$ mlky M'n [line 2] and ['l]yf' Rym mlk M'n [lines 8-9] and RES 2952: 'byd' Y $\underline{t}$ $w$-Wqh'l Ry[m mlk]y M'n [line 1] and 'byd' $Y \underline{t}^{\prime}$ mlk [M] 'n [line 4]; this latter text is contemporary to the historical scenario discussed here)

12 Cf. inscription Y.92.B.A.21+30.

13 de Maigret - Robin 1993, 455. The measurements presented here follow the careful re-evaluation made by F.G. Fedele. 
to consider this result a terminus post quem and to cautiously date within the lower end of the identified interval (i.e. late $5^{\text {th }}$ century $\mathrm{BC}$ ). Of note, the temple Qabdum was inaugurated close to the end of Waqih' il Riyām's reign, as he is mentioned together with a coregent; we should conclude that he had a fairly long reign, concentrated in the last decades of the $5^{\text {th }}$ century BC. This may be a good working hypothesis to evaluate in light of the wider historical panorama, with the support of further documentation. Inscriptions realized under this sovereign reveal a congruent paleographic style, sensibly evolving from E2 to E3 (according to Pirenne's framework). ${ }^{14}$

\section{SUCCESSOR TO KING WAQIH'IL RIYĀM}

The abovementioned Y.05.B.B.12 appears to associate Waqih'il Riyām with his son, Aws'il, as coregent; however, Waqih'il Riyām also had a further son and coregent, Huffān Sadiq (RES 3051+3052a; RES 3040+3039+3049). Therefore, the identity of the successor to Waqih'il Riyām remains in doubt. There is no evidence that a King Aws'il ever reigned alone, as the name Aws'il is undocumented in royal onomastics, though it appears quite regularly as a personal name for commoners $;{ }^{15}$ should we thus hypothesize that Aws'il was a birth name that was eventually replaced by an official name - maybe after the formal enthronization as coregent? In this case, Aws'il and Huffān Șadiq could hypothetically be the same person. The possibility that Huffān Șadiq ever succeeded to Waqih il Riyām is also very doubtful: though some inscriptions mention a King Huffān Șadiq, they do not use a patronymic, thus it is impossible to say if he is the same Huffān Sadiq previously mentioned as coregent; moreover, graphic documentation is lacking for these texts and we cannot comment on their paleographic style and, consequently, their relative chronology (RES 2886 and M 414). ${ }^{16}$

The possibility that Waqih'il Riyām's successor was another of his sons has been raised, citing evidence of a couple of texts in a style close to E3, in which a King Abikkarib Sadiq is mentioned with the patronymic Waqih il (Robin-Barāqish 80 and Shaqab 4). ${ }^{17}$ At present, this King Abīkarib Șadiq is not attested to have been coregent with Waqih'il Riyām, unless we recognize him as Aws'il - but this would be too speculative. In any case, this phase remains quite nebulous, but we can perceive that the end of Waqih'il Riyām's

14 Pirenne 1956, 218-224. Bron 2013 is the funerary stela of King Waqih'il Riyām (fig. 3) and can be consequently attributed with certainty to the final period of his reign (Bron 2013, 173-174, fig. 1).

15 Approximately 13 Minaean funerary stelae bear this name, either isolated or as a first name, suggesting that it was a fairly common name in the Minaic onomastics. Other attestations from Barāqish are in M 283 (three times, as a name of commoners and as a patronymic); and as-Sawdā' 16, where it is the first name of the priest $\left(s^{2} w^{\prime}\right)$ of dhu-Garbum and dhu-Rașfum.

16 Von Wissmann postulates the presence of two kings named Huffān Șadiq: the king mentioned in RES 2886 and RES 2762 is a more ancient homonym, to be distinguished from Waqih'il Riyām's son (von Wissmann 1976, 373). The highly incomplete text RES 3050 has seldom been attributed to this coregency, but this is only due to a strong integration; therefore, it is not considered in the present discussion: [Wqh'l Rym bn 'b]yd' $w$-bn-s ${ }^{1} H f n$ S $d q$ (cf. Pirenne 1956, 218).

17 RES 2965 might also be considered even if without the patronymic: the text is in fact still in situ in the southern portion of the urban walls of Barāqish, an area involved in strong architectural interventions at the time of this dynasty (cf. fig. 1); Robin-Barāqish 80 reveals some paleographic dissimilarities compared to RES 2965 and Shaqab 4 (Robin 1979, 193-194). 
reign must have been quite turbulent. He had at least two consecutive coregents among his sons, potentially because one was disowned or died prematurely. ${ }^{18}$ Finally, it is highly probable that his successor was another of his sons, Abīkarib Șadiq, and, if Huffān Șadiq was one of his successors, we cannot exclude the possibility that he was temporarily deposed by Abīkarib Șadiq (his brother?) - a possibility that is unverifiable until the paleography of the texts pertaining to this king are tested.

\section{DATING OF King ABĪYADA' YATHA 'AND THE PERSIAN-MinAEAN SYNCHRONISM}

The dating of King Waqih'il Riyām must be considered together with the chronology of his father and predecessor, King Abiyada' Yatha'. ${ }^{19}$ This requires a retrospect of the major epigraphic document realized under the reign of Abīyada' Yatha', i.e. RES 3022 - still engraved on the southern portion of the Minaean walls of Barāqish (fig. 4). This wellknown, fundamental document is one of the few South Arabian texts indicating an external synchronism. The text has been at the center of a long debate since the first copies by Halévy and Glaser were made available (late $19^{\text {th }}$ century). An overview of the still growing bibliography concerning this text reveals how its dating has been far from unanimous, spanning the late $6^{\text {th }}$ to the late $3^{\text {rd }}$ century BC.

In the present paper, it is sufficient to briefly recapitulate only the most sensitive points of the very well-known debate over this text. ${ }^{20}$ The text was commissioned by members of a Minaean caravan after their return to their homeland following a long and difficult commercial trip to the north of the peninsula and Egypt. During their journey, they witnessed several military clashes, which they briefly recorded in the text while thanking the divinities for their protection. ${ }^{21}$ Among these events, one apparently had a vast resonance:

... w-ywm $m t^{\prime}-s^{1} m w-{ }^{\prime} q n y-s^{1} m$ 'ttr $\underline{d}-Q b d m w-W d m w-N k r h m b n$ ws ${ }^{1} t$ Mṣr $b{ }^{(3)} m r d k w n$ byn $M \underline{d} y$ w-Mṣr ... (RES 3022/2-3).

"... and when 'Athtar dhu-Qabḍum, Waddum and Nakrahum saved them and their goods in the middle of Egypt, during the conflict which occurred between Persians and Egypt..." (DASI translation).

While the term Mṣr does not pose any problem, as its connection with the toponym Egypt is clear, the most critical issues pertaining to this text are the identification of the term $M \underline{d y}$ and the semantic nuance of the term $m r d .^{22}$ With respect to $M \underline{d} y$, which is

Agostini 2011.

In turn, a dating of King Abīyada' Yatha' would also affect that of the contemporary King of Hadramawt, Ilīsami` Dhubyān, according to RES 2775 (Ma īn 8).

20 An updated review of the secondary literature is in Multhoff (2019); see also Gnoli 1996; Lemaire 2010; Avanzini 2016, 159-162.

21 In addition to trading with Egypt, they also connected with Assyria (' $s^{2} r$ ) and Transeuphratene ('br nhrn) They escaped attacks from Saba' and Khawlān, while also surviving a war between "the one of the south and the one of the north" (dr kwn byn $\underline{d}-y m n t w-\underline{d} s^{2}$ 'mt).

22 Lemaire 1996, 44-47; Lemaire 2010, 381-383. 
generally referred to as an ethnonym, several definitions have been proposed, including: the Medes, ${ }^{23}$ the Persians (the vast majority of scholars), and the Seleucids. ${ }^{24}$ These hypothetical identifications could be accepted, in principle, as all of the abovementioned entities have been indicated in ancient documentations as Medes - even the Seleucids. ${ }^{25}$

The difficulty of translating the term $m r d$ was initially raised by André Lemaire, who noted that the usual translation of "war, conflict" is not appropriate, as the South Arabian term for "war" is $d r$ - a lexeme that is in fact used for this semantic purpose in the same RES 3022 (line 2). Lemaire consequently proposed the translation of "revolt," but the use of the preposition byn ("between") would indicate that this action had a reciprocal nature, which is not entirely suitable as far as a revolt is concerned. Considering all these premises, the actual event may have occurred within the timespan of 525 to 217 BC. During this long interval, several possible events known to us could fit with the Minaean synthetic account, but none imposes itself as a clear, unambiguous solution. In particular, Mlaker sustained the possibility that the event was the invasion of Egypt by Cambyses in $525 \mathrm{BC}$, while Pirenne proposed the war between the Seleucids and Lagidis in 217 BC. ${ }^{26}$ Currently, the identification that has received the most consensus is the Persian invasion of Egypt by Artaxerxes III Ochus in 343 BC, which was suggested by F.V. Winnett, accepted by W.F. Albright, and finally backed by G. Gnoli, not without some hesitation. ${ }^{27}$ As already anticipated, Lemaire noted that the event may have been a revolt, and he suggested a couple of events in the $5^{\text {th }}$ century BC, such as those under Inaros (463-454 ca.) and Amyrtheus (405-398 ca.), with a slight preference for the latter. ${ }^{28}$ However, as rightly pointed out by Beeston, the possibility that the event was actually one of a number of «minor brushes which, though they do not catch the attention of the historian, may have had a lasting impressions on the Minaeans», should also be considered. ${ }^{29}$

The debate over RES 3022 has been recently revived, thanks to a penetrating article by Anne Multhoff, whose main topic was the inscription of Demirjian 1 (=B-L Nashq ?). This Sabaic text appeared in 2009 and has great historical implications, as it mentions several events - both internal and external - including a controversial war between Chaldea and Ionia (lines 15-16: $\left.d r K s^{2} d m w-Y w n\right) .{ }^{30}$ According to Multhoff, Demirjian 1 and RES 3022 reveal a similar historical background, and thus their dating may not be too distant. This inductive approach relies on the observation that both seem to reflect a similar external political situation and share a few lexical and stylistic parallelisms. ${ }^{31}$ Paleographic comparison may also be employed, even if Demirjian 1 is a bronze plaque while RES 3022 is engraved on the limestone blocks of urban walls, apparently by different scribal

Mlaker 1943.

Pirenne 1956

Gnoli 2005

Mlaker 1943, 97; Pirenne 1956, 211-213.

Winnett 1939; Albright 1953; Gnoli 1996; Gnoli 2005.

Lemaire 1996, 47; Lemaire 2010, 383. This hypothesis is also supported by Sørensen - Geus (2019, 203).

Beeston 1984, 4.

30 The subject, a contemporary of the Sabaean King Yada "il Bayyan, son of Yatha "mar, recalls an attack against a Minaean caravan, an expedition to the land of Hadramawt, and several other commercial expeditions to Dedan, Gaza, and the cities of Judah, having also established contacts with Kition (Cyprus)

31 Multhoff 2019, 8 . 
schools. ${ }^{32}$ Although lacking indisputable evidence, this hypothesis is very interesting; however, even if we were to accept it, we must still reflect on the contentious dating of Demirjian 1, which has been dated by the first editors to $600 \mathrm{BC}^{33}$ and 550-525 $\mathrm{BC}^{34}$; furthermore, a younger date of the early $4^{\text {th }}$ century BC was proposed by Peter Stein, backed by Sørensen and Geus from the classicist historian's perspective, and finally accepted by Multhoff, as well. ${ }^{35}$ An early $4^{\text {th }}$ century BC dating for Demirjian 1 would also confirm a dating of RES 3022 to the late $5^{\text {th }}$ century BC. ${ }^{36}$

This archaeological datum could enable us to clarify the age of this important epigraphic material without falling victim to circular reasoning. The hypothesis that Waqih il Riyām reigned in the late $5^{\text {th }}$ century BC is suggested by the radiometric result, as well as by the historical deduction based on inscriptions. Consequently, Abīyada' Yatha's long reign could have spanned the mid- $5^{\text {th }}$ century, and the redaction of RES 3022 should be placed at the apogee of his reign, as he reigned alone. With respect to the MinaeanPersian synchronism, a possible adjustment could be admitted, as a certain interval must be considered between the event recorded and the realization of the inscription. In this perspective, the identification of the Minaean-Persian synchronism would point more closely to an event that occurred between the revolts under Inaros around the middle of the $5^{\text {th }}$ century BC (463-454), or to an unregistered event that occurred a few years later, but before the brief insurrection in the second year of Darius II (422 BC), as reported by Syncellus. ${ }^{37}$

\section{ABĪYADA' YATHA ' WITH A NEW COREGENCY, AND ITS HISTORICAL SETTING}

The enlargement of the small extra-muros sector corresponding to recesses 44-45 of the southwest urban walls permitted the exposition of some rows of the urban walls that had previously remained covered by external debris. This led to the discovery of new inscribed blocks pertaining to the walls, which notoriously present a huge number of inscriptions. Particularly interesting are a series of three blocks that were not in situ but repositioned during the Islamic restoration of the walls; even if displaced, they certainly pertained to this area of the walls (fig. 5). Their inscriptions were collated to reveal an incomplete text commemorating the dedication of a new building operation in the walls (in this case, relating to the tower dhu-Nabdān and its curtain Tafish). The combination of fragments also discloses a royal name, Abìyada' Yatha' - seemingly the same king mentioned in RES 3022 and the father of Waqih'il Riyām. The paleographic analysis of the text (style E2) confirms

Multhoff 2019, 10-11 (see also Appendix 2 by P. Stein at the end of Multhoff's article).

33 According to Bron - Lemaire (2009, 19-29), the war between "Ionia" and the "Chaldeans" may have occurred during the Neo-Babylonian period, probably under Nebuchadnezzar II.

34 According to de Maigret - Robin (2009, 93, 95-96), relying on the historical synthesis by S. Anthonioz, the war could be placed under the reign of Neriglissar (559-556 BC) or Nabonidus (556-539 BC).

35 The war between the Persians and Euagoras could be the most probable solution for this synchronism, according to Stein (2017, 100), Multhoff (2019, 12-13), and Sørensen - Geus (2019, 199-200).

36 Multhoff $(2019,12-13)$ postulates that RES 3022 may be older than Demirjian 1 by some decades. If so, the Persians would be indicated by two different ethnonyms: $M \underline{d} y$ in the Minaic text and $K s^{2} d m$ in the Sabaic text; this would be the main weakness of this hypothesis. The lowering of the date of Demirjian 1 to the early $4^{\text {th }}$ century is not accepted by Arbach (2019).

37 Lemaire 1996, 47. 
this identification. The text also indicates a new coregent to Abìyada' Yatha', who had previously been thought to have a single coregent: his son and successor, Waqih'il Riyām. The new collated text indicates:

$$
{ }^{\prime} b y d^{\prime} \pm Y \underline{t}^{\prime} w-b n-s^{1} H y w m \text { mlky M'nm (Y.03.B.R44-45.2bis + 2ter + 2/2) }
$$

The presence of multiple coregents with Abīyada' Yatha' resembles the situation of his son, Waqih'il Riyām. While Hayyūm was not previously associated with Abīyada ' Yatha', his name is already cited in the royal onomastics (without mimation): M 283 includes it as a royal patronymic, together with an epithet (line 5: 'byd' Rym bn Hyw Sdq), while the royal status of the individual $H y w$, mentioned together with $Y^{\prime \prime} l$ in RES 2772 and Ma'in 18, is probable but not proven. In both cases, we can safely exclude an identification with our newly attested Hayyūm, because of the paleographic and chronological distance. While the swapping in the role of coregent is highly unusual, we can resume the hypotheses already put forward in the case of Aws'il, Waqih'il Riyām's son; however, it is remarkable that this phenomenon occurred twice, in two consecutive reigns. The existence of these multiple coregencies leaves the Minaean institution rather unclear: as already pointed out by Jacques Ryckmans, the function of the coregencies may not have been limited to assuring smooth successions. $^{38}$

Another fragmentary text (Y.03.B.R44-45.3) from this same sector can be considered contemporary to Abīyada' Yatha'. Again, this hypothesis relies on a paleographic analysis, as well as the mention of a kabir of Yathil named 'Ammīsami', because RES 3022, RES 2959, and Y.92.B.A. 21+30 (all from the time of Abiyada' Yatha') indicate that a man called 'Ammīsami' dhu-Balih was kabìr of Yathil. The historical importance of this new text relies on a brief mention of a "siege of the town of Yathil" ( $s^{3} w k t h g r n$ Y $\left.t l\right)$, before the interruption of the block in line 4. This brief reference likely reflects an important event during the reign of Abiyada' Yatha', and it should be considered in our reconstructed historical panorama. We know that during the reigns of Abiyada' Yatha ' and Waqih'il Riyām, the Minaean kingdom consolidated its political position and gained great prosperity, as also revealed by the extensive building activity that was launched - especially at the site of Yathil, which was then firmly under the control of the Minaeans, following a long period of Sabaean rule. This new situation was probably reached with some conflict, especially in this area at the border with the Sabaean kingdom. Ma īn struggled to dominate the entire Jawf, and the epigraphic documentation from this period reveals several tensions between Saba' and Ma'in. As already stated, RES 3022 recalls that the Minaean caravan suffered a Sabaean attack at the beginning of their journey through the north. Some time later, Waqih'il Riyām may have experienced further instability relating to the Sabaean neighbor, as a dedication made to some Sabaean divinities could be symptomatic of a Sabaean hegemony over Ma'in, if only temporary (Shaqab 18). Thus, it is quite probable that Abīyada' Yatha' experienced some violent attacks with Saba' during his reign, and Saba' is likely to have been the opposing force associated with the siege mentioned in this newly uncovered fragmentary inscription from the urban walls.

38 Ryckmans 1951, 42-46. 


\section{THE PREDECESSOR OF KING ABĪYADA ' YATHA}

The beginning of the dynastic segment that comprises the reigns of Abiyada' Yatha' and his son Waqih'il Riyām remains greatly uncertain. Abīyada ' Yatha' is never mentioned with a patronymic, nor is he clearly attested as a coregent in second position. An Abiyada, without epithet, is associated with an Iliyafa' Yatha' in RES 2789, in the formula $b-y w m$ ' $l y f^{\prime} Y t^{\prime} w$ - 'byd'. Pirenne classified this inscription as style C4; however, the identification of this Abìyada' with Abìyada' Yatha' is admitted by von Wissmann. ${ }^{39}$ The occurrence of Ilìyafa' Yatha' as a patronymic in the fragmentary RES 2835 could be more solidly attributed to this period, as its paleography is closer to Pirenne's "E stage." A connection between Abīyada' Yatha' and a King Iliyafa' Yatha' could be further sustained by the reference to the "sons of Ma'dikarib son of Ilīyafa' Yatha' King of Ma'īn" (bhny M'dkrb $b n$ ' $l y f^{\prime} Y \underline{t}^{\prime} \mathrm{mlk} M^{\prime} \mathrm{n} m$ ) in RES 3012 - again evoked in the final dedication of RES 3022 which is clearly contemporary to Abìyada' Yatha'. This Ma'dikarib, son of King Ilìyafa' Yatha', is certainly a member of the royal family - possibly an older relative of Abiyada' Yatha' - representing a collateral dynastic line with influence in Minaean society. ${ }^{40}$ Thus, there is strong evidence to suggest that Ilìyafa' Yatha' preceded Abīyada' Yatha', though this is not entirely proven.

\section{NEW ATTESTATIONS OF KING ILİYAFA' YAFASH}

The Minaean King Ilīyafa' Yafash is rarely mentioned, and only in fragmentary texts. Pirenne considered him a grandchild of Abīyada' Yatha', while von Wissmann and Kitchen considers him a predecessor. ${ }^{41}$ In fact, the placement of Iliyafa' Yafash within the Minaean royal succession is still quite problematic, because a clear connection between the sovereigns is lacking, given that they are not linked by any coregency, patronymic, or direct succession. A king named Ilīyafa' Yafash was seemingly a coregent with Huffān Șadiq, as he is cited in second position in a very fragmentary text, probably from Haram (RES 2762). Although the text does not preserve the royal title, there is little doubt that the two shared the throne, with Huffān Șadiq as first king. As previously anticipated, all inscriptions pertaining to King Huffān Șadiq are lacking iconographic documentation and paleographic analysis; thus, it is difficult to detect possible homonyms or to pinpoint a clear relative chronology (see above, $\S 5$.). A second very partial inscription mentioning Ilīyafa' Yafash is RES 2982, in which only a few letters are preserved; again, this inscription is not supported by any figurative documentation.

Considering the paucity of the documentation pertaining to a King Ilīyafa' Yafash, the discovery of two new texts mentioning this royal name is particularly significant. Y.06.B.B.11 was found re-employed in an Islamic wall built over the area occupied by the ancient temple Qabdum, and it is a legal prescription relating to the agricultural domain, devoid of any further historical information.

39 All the inscriptions pertaining to these kings are classified in his Paläographische Stufe III (von Wissmann 1976, 382-386)

40 Pirenne 1956, 222-224

41 Pirenne 1956, 222-224; Kitchen 1994, 51-56; von Wissmann 1976, 66-67, 101. 
A King Ilīyafa' Yafash is also mentioned in a newly exposed but again very incomplete text from the external sector, in proximity to the urban walls (Y.04.B.T45.1). The paleographic style of this text is closer to general style E, but quite dissimilar to the style of Y.06.B.B.11. Therefore, we cannot exclude that the name Iliyafa' Yafash mentioned in Y.04.B.T45.1 and Y.06.B.B.11 could refer to two different kings of the same name, but the slight paleographic discrepancy between these two texts could also be explained by their different textual typology. However, a connection with the Ilīyafa' Yafash mentioned as coregent in RES 2762 still remains doubtful, just as the entire last segment of the dynasty following the reign of Waqih'il Riyām.

\section{REFERENCES}

Agostini, A.

2011 Two new inscriptions from the recently excavated temple of 'Athtar dhū-Qabd in Barāqish (Ancient Minaean Yathill): Arabian Archaeology and Epigraphy 22 (2011), pp. $48-58$.

2015 The excavation of the temple of 'Athtar dhu-Qabḍ in Barāqish. Stratigraphic data and historical reconstruction: Proceedings of the Seminar for Arabian Studies 45 (2015), pp. $1-14$.

2018 The Jawf Valley as a crossroad: Some observations about the tribe of Amīr in South Arabia: ARAM 30 (2018), pp. 355-368.

2020 Seasonal offerings among the Minaeans. The case of ancient Yathil: Arabian Archaeology and Epigraphy 31 (2020) [published online on 16 April 2020].

ALBRIGHT, W.F.

1953 The chronology of the Minaean kings of Arabia: Bulletin of the American School of Oriental Research 129 (1953), pp. 20-24.

ARBACH, M.

2019 L'Arabie du Sud au VI ${ }^{\mathrm{e}}$ siècle avant l'ère chrétienne et le synchronisme avec le Levant: Ex Oriente lux. Sbornik statei k 75-letiiu Mikhaila Borisovicha Piotrovskogo, Saint Petersburg 2019, pp. 58-67.

AvANZINI, A.

2016 By land and by sea. A history of South Arabia before Islam recounted from inscriptions (Arabia Antica 10), Roma 2016.

BEESTON, A.F.L.

1984 Chronological problems of the Ancient South Arabian culture: A.T. AL-ANSARY (ed.), Studies in the History of Arabia, vol. 2: Pre-Islamic Arabia, Riyadh 1984, pp. 3-6.

BRON, F.

2013 Notes d'épigraphie minéenne: Semitica 55 (2013), pp. 173-178.

BRON, F - LEMAIRE, A.

2009 Nouvelle inscription sabéenne et le commerce en Transeuphratène: Transeuphratène 38 (2009), pp. 11-29.

DE MaIGRET, A.

2009 The excavations of the Italian Archaeological Mission at Barāqish (Republic of Yemen): Newsletter Archeologia 0 (2009), pp. 50-90. 
DE MAIGReT, A. - RoBin, C.J.

1993 Le temple de Nakrah à Yathill (aujourd'hui Barāqish), Yémen, résultats des deux premières campagnes de fouilles de la Mission Italienne: Comptes rendus des séances de l'Académie des Inscriptions et Belles-Lettres 137 (1993), pp. 427-498.

2009 Le royaume sudarabique de Ma'īn. Nouvelles données grace aux fouilles Italiennes de Barāqish (l'antique Yathill). Note complémentaire sur la guerre entre la Chaldée et l'Ionie par Mme Stéphanie Anthonioz: Comptes Rendus des séances de l'Académie des GNOLI, G. Inscriptions et Belles Lettres 153 (2009), pp. 57-96.

1996 Il sincronismo mineo-persiano: C.J. RobIN - I. GAJDA (eds.), Arabia Antiqua. Early origins of South Arabian states (Serie Orientale Roma LXX, 1), Roma 1996, pp. 23-34.

2005 Ancora sui "Medi" in RES 3022: A. ShOlan, S. ANTONINI - M. ARBACH (eds.), Sabaean Studies. Archaeological, epigraphical and historical studies in honour of Y.M. Abdallāh, A. de Maigret, Ch.J. Robin. Napoli - Șan'à' 2005, pp. 295-300.

JUNG, M.

1989 The religious monuments of ancient Southern Arabia. A preliminary typological classification: Annali dell'Istituto Orientale di Napoli 48 (1989), pp. 177-218.

KITCHEN, K.A.

1994 Documentation for ancient Arabia. Part I: Chronological framework and historical sources, Liverpool 1994.

LEMAIRE, A.

1996 Histoire du Proche-Orient et chronologie sudarabique avant Alexandre: C.J. RoBIN - I. GAJDA (eds.), Arabia Antiqua. Early origins of South Arabian states (Serie Orientale Roma LXX, 1), Roma 1996, pp. 35-48.

2010 Chronologie sabéenne et minéenne et histoire du Proche Orient: Orientalia 79 (2010), pp. 379-389.

MLAKER, K.

1943 Die Hierodulenlisten von Ma`in nebst Untersuchungen zur altsüdarabischen Rechtsgeschichte und Chronologie (Sammlung Orientalistischer Arbaiten, 15), Leipzig 1943.

Multhoff, A

2019 Merchant and marauder - The adventures of a Sabaean clansman: Arabian Archaeology and Epigraphy 30 (2019), pp. 239-262.

PIRENNE, J.

1956 Paléographie des inscriptions sud-arabes, contribution à la chronologie et à l'histoire de RoBIN, C.J. l'Arabie du Sud antique. I. Des origines jusqu'à l'epoque Himyarite, Brussels 1956.

1979 Mission archéologique et epigraphique francaise au Yemen du Nord en automne 1978: Comptes Rendus des séances de l'Académie des Inscriptions et Belles Lettres 123 (1979), pp. 174-203.

RYCKMANS, J.

1951 L'institution monarchique en Arabie méridionale avant l'Islam (Ma ìn et Saba'), Louvain 1951.

SCHMIDT, J.

1997 Tempel und Heiligtümer in Südarabien. Zu den materiellen und formalen Strukturen der Sakralbaukunst: Nürnberger Blätter zur Archäologie 14 (1997), pp. 11-41.

SøRENSEN, L.S. - GEUS, K.

2019 A Sabaean eyewitness to the war of Euagoras against the Persians: Zeitschrift für Papyrologie und Epigraphik 209 (2019), pp. 196-204. 
STEIN, P.

2017 Sabäer in Juda, Juden in Saba. Sprach- und Kulturkontakt zwischen Südarabien und Palästina in der Antike: U. HÜBNER - H. NIEHR (hrsg.), Sprachen in Palästina im 2. und 1. Jahrtausend v.Chr. Kolloquium des Deutschen Vereins zur Erforschung Palästinas 02.04. 11. 2012, Mainz (Abhandlungen Des Deutschen Palästina-Vereins, 43), Wiesbaden 2017, pp. 91-120.

VON WISSMANN, $\mathrm{H}$.

1976 Die Geschichte des Sabäerreichs und der Feldzug des Aelius Gallus: W. HaASE - H. TEMPORINI (hrsg.), Austieg und Niedergang der Römischen Welt II, IX/1 (1976), pp. 308544.

WINNETT, F.V.

1939 The place of the Minaeans in the history of pre-Islamic Arabia: Bulletin of the American School of Oriental Research 73 (1939), pp. 3-9. 


\begin{tabular}{|c|c|c|c|c|}
\hline Sigla Inscriptions & Citation & $\begin{array}{c}\text { Style } \\
\text { Pirenne } \\
1956\end{array}$ & King(s) & $\begin{array}{l}\text { Other historical and } \\
\text { archaeological data }\end{array}$ \\
\hline RES 2835 & 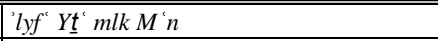 & & Ilīyafa' Yatha' & \\
\hline RES 2789 & $b-y w m^{\prime} l y f^{\prime} Y \underline{t}^{\prime} w$ - $^{\prime} b y d^{\prime}$ & $\mathrm{C} 4$ & $\begin{array}{l}\text { Ilīyafa' Yatha' } \\
\text { and Abīyada' }\end{array}$ & \\
\hline GOAM 315 & byd'Y $\underline{t}^{\prime} m l k M{ }^{\prime} n$ & & \multirow{9}{*}{ Abīyada' Yatha' } & \\
\hline RES 2774 & 'byd'Y $Y \underline{t}^{\prime} m l k M{ }^{\prime} n$ & E2 & & \\
\hline RES 2775 & 'byd' $Y \underline{t}{ }^{\prime} m l k M^{\prime} n m$ & E2 & & $\begin{array}{l}\text { Synchronism: Ilīsami } \\
\text { Dhubyān, son of } \\
\text { Malkīkarib, King of } \\
\text { Ḥaḍramawt }\end{array}$ \\
\hline RES 2959 & 'byd' $Y \underline{t}{ }^{\prime}$ & & & \\
\hline $\begin{array}{l}\text { RES } \\
2972+2970+2971+297 \\
1 \text { bis B }+2971 \text { bis A }\end{array}$ & 'byd'Yt' mlk M['nm] & & & \\
\hline RES 3006 & [']byd'Yt $\left[\underline{t}{ }^{\prime} \ldots\right]$ & & & \\
\hline RES 3022 & 'byd' $Y \underline{t}{ }^{\prime} m l k M ' n$ & E2 & & $\begin{array}{l}\text { Synchronism: conflict } \\
\text { between Mdy and Mṣr }\end{array}$ \\
\hline RES 3029 & 'byd' $Y \underline{t^{\prime}}$ & & & \\
\hline Y.92.B.A $21+30$ & byd $Y \underline{t^{\prime}}$ & $\mathrm{E} 2$ & & \\
\hline $\begin{array}{l}\text { Y.03.B.R44-45.2bis + } \\
\text { 2ter }+2\end{array}$ & 'byd' Yt ' ${ }^{\prime} w-b n-s^{1}$ Hywm mlky M'nm & E2 & $\begin{array}{c}\text { Abīyada' Yatha' } \\
\text { and Hayyūm }\end{array}$ & \\
\hline $\begin{array}{l}\text { Bauer } 5 \\
{[=\mathrm{Gr} 301+\mathrm{Gr} 299+\mathrm{RES}} \\
2962+\mathrm{Gr} 303]\end{array}$ & 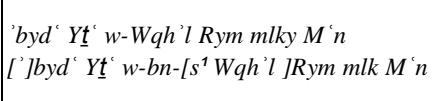 & E2 & \multirow{8}{*}{$\begin{array}{c}\text { Abīyada' Yatha' } \\
\text { and Waqih'il } \\
\text { Riyām }\end{array}$} & \\
\hline RES 2929 & 'byd'Y $\underline{t}^{\prime} w$-Wqh'l Rym & & & \\
\hline $\begin{array}{l}\text { RES } 2942+\text { two } \\
\text { fragments }\end{array}$ & {$[\ldots w$-Wqh]'l Rym mlky M'nm } & & & \\
\hline RES 2944 & [']byd'Yt' $w$-Wqh'l [...] & & & \\
\hline RES 2952 & 'byd $Y \underline{t}^{\prime} w$-Wqh'l Ry[m mlk]y M'n & E3 & & \\
\hline RES 3012 & $\begin{array}{l}\text { ['byd'] Yt' } w \text {-Wqh'l [Ry]m } \\
\text { ['by]d' Yt' }\left[w-W q h^{\prime} l \text { Ry]m }\right.\end{array}$ & E2 & & \\
\hline RES 3013 & ['byd'Y]t’ $w$-Wqh'l Rym mlky M'n & & & \\
\hline RES 3535 & 'byd'Y $\underline{t}^{\prime} w$-Wqh'l Rym mlky M'n & E1-E2 & & \\
\hline Bron 2013 & Wqh'l Rym & E3 & \multirow{8}{*}{ Waqih' il Riyām } & \\
\hline M 415 & Wqh'l [Rym ...] & & & \\
\hline RES 3005 & {$[W] q h ' l$ Rym } & & & \\
\hline RES 3055 & {$[$ W]qh'l Rym bn 'b[yd'...] } & & & \\
\hline Shaqab 18 & Wqh'l Rym bn 'byd' mlk M'nm & E2-E3 & & \\
\hline Y.90.B.ext. 2 & [W]qh'l Rym mlk M'n & E3 & & \\
\hline Y.05.B.B.13 & Wqh'l Rym mlk M'n & E3 & & \\
\hline Y.06.B.B.6 & Wqh'l Rym mlk M'nm & E3 & & \\
\hline Y.05.B.B. 12 & Wqh'l Rym w-bn-s' 'ws 'l l mlky M'nm & E3 & $\begin{array}{c}\text { Waqih' il Riyām } \\
\text { and Aws'il }\end{array}$ & $\begin{array}{c}\text { Bar.05.B/2a } \\
{[14 \mathrm{C}: 593-406 \text { BCE] }}\end{array}$ \\
\hline RES 3040+3039+3049 & Wqh'l Rym w-bn-s ${ }^{1} H$ fn S Sdq mlky M'n & E3 & \multirow{2}{*}{\begin{tabular}{|c|} 
Waqih' il Riyām \\
and Ḥuffān Ṣadiq
\end{tabular}} & \\
\hline RES $3051+3052 \mathrm{a}$ & Wqh'l Rym w-bn-s ${ }^{1} H f n[S S d q \ldots]$ & & & \\
\hline
\end{tabular}




\begin{tabular}{|c|c|c|c|c|}
\hline RES 2965 & 'bkrb Șlq mlk M'nm & E3 & \multirow{3}{*}{ Abīkarib Șadiq } & \\
\hline Robin-Barāqish 80 & 'bkrb Șlq bn Wqh'l & E? & & \\
\hline Shaqab 4 & 'bkrb Șdq bn Wqh'l mlkh M n & E3 & & \\
\hline $\mathrm{M} 414$ & {$\left[\ldots\right.$ H]fnm Șdq $m\left[l k M^{\prime} n \ldots\right]$} & & \multirow{2}{*}{ Ḥuffān Șadiq } & \\
\hline RES 2886 & 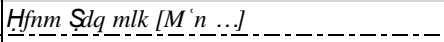 & & & \\
\hline RES 2762 & $H f n S S l q w^{\prime} l y f^{\prime} Y f s^{2}$ & & \begin{tabular}{|} 
Huffān Șadiq and \\
Ilīyafa Yafash
\end{tabular} & \\
\hline RES 2982 & "lyf $Y f\left[s^{2} \ldots\right]$ & & \multirow{3}{*}{ Ilīyafa Yafash } & \\
\hline Y.04.B.T45.1 & $' l y f^{\prime} Y f s^{2}$ & E? & & \\
\hline Y.06.B.B.11 & 'lyf' $Y f^{2}{ }^{2} m l k M i n$ & E3 & & \\
\hline
\end{tabular}

Tab. 1 - The possible succession of the Minaean kings during the $5^{\text {th }}$ and $4^{\text {th }}$ centuries $\mathrm{BC}$, according to the epigraphic and archeological documentation discussed (new data in bold). Dashes lines indicate uncertain successions. Most of the inscriptions are from Barāqish, except RES 2835, RES 2789, RES 2774, RES 2775 (from Ma'īn), Shaqab 4 and Shaqab 18 (Shaqab al-Manașșa), RES 2886 (as-Sawdā'), RES 2762 (prob. Haram), and Bron 2013 (origin unknown)

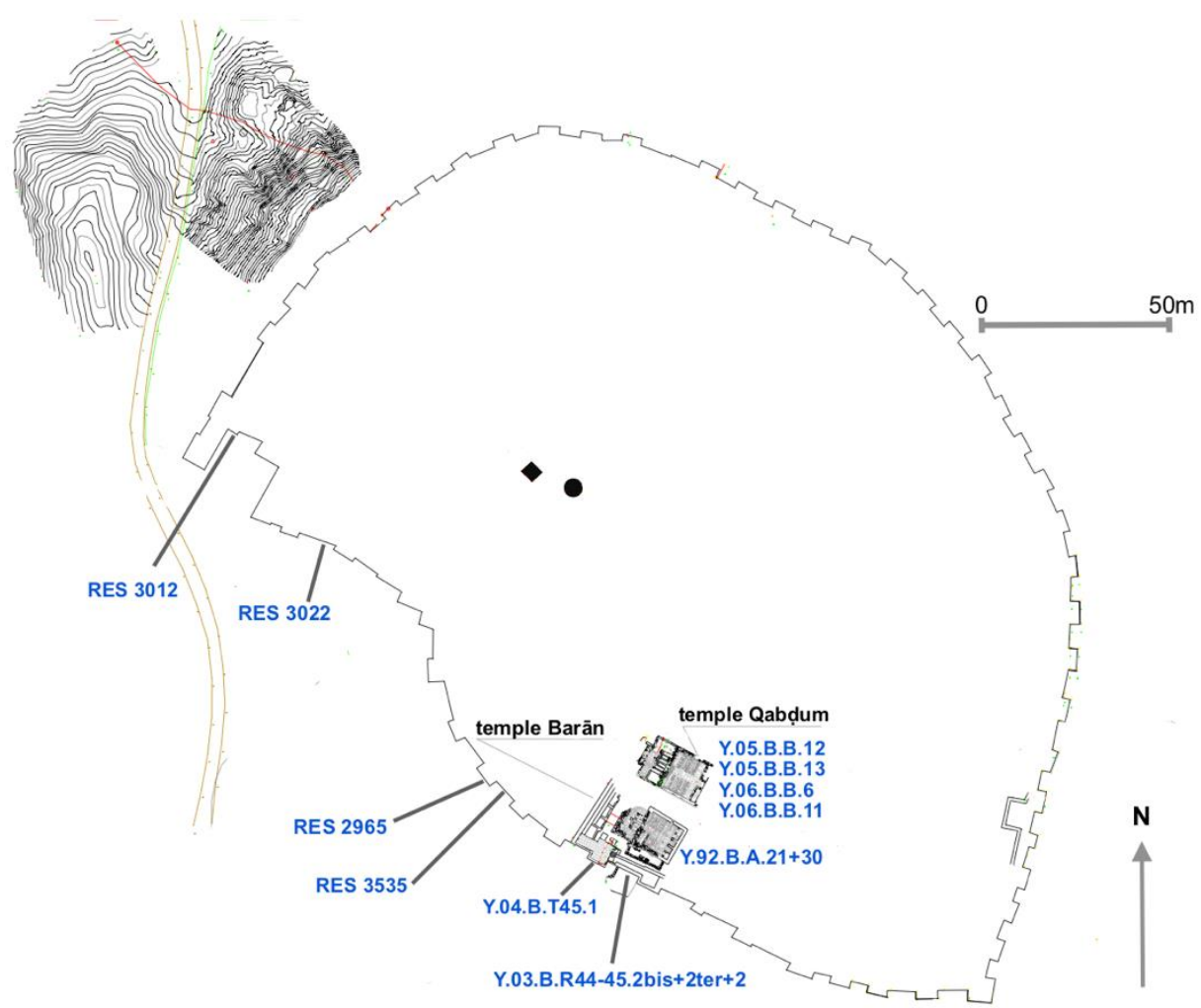

Fig. 1 - Plan of the site of Barāqish, with localization of the most relevant inscriptions discussed (C MAIRY, elaboration by A. Agostini). 


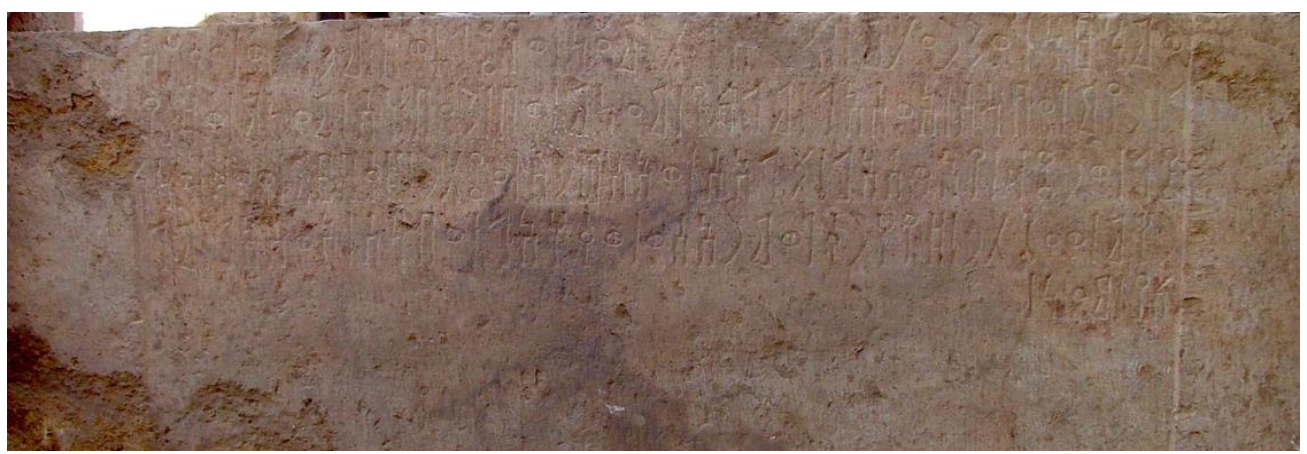

Fig. 2 - Y.05.B.B.12, time of the coregency of King Waqih'il Riyām and his son Aws'il (CMAIRY).

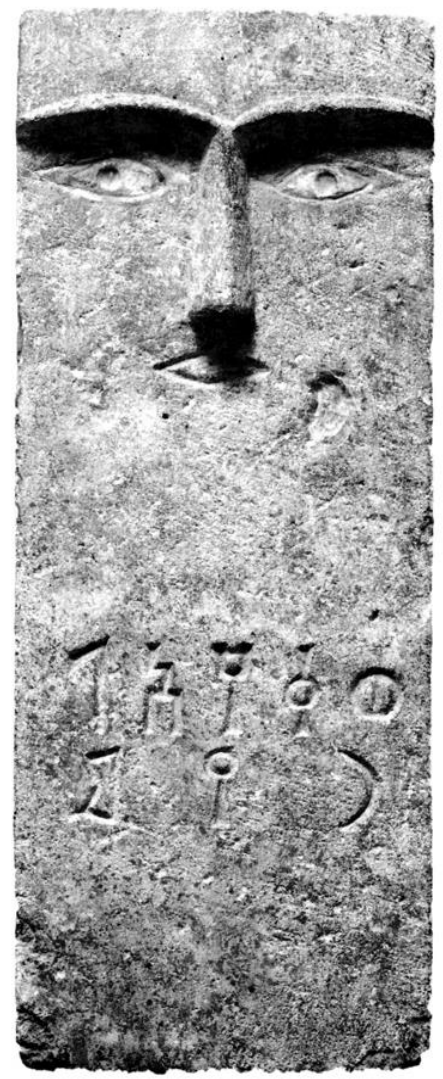

Fig. 3 - The funerary stela of King Waqih'il Riyām (Bron 2013, fig. 1). 


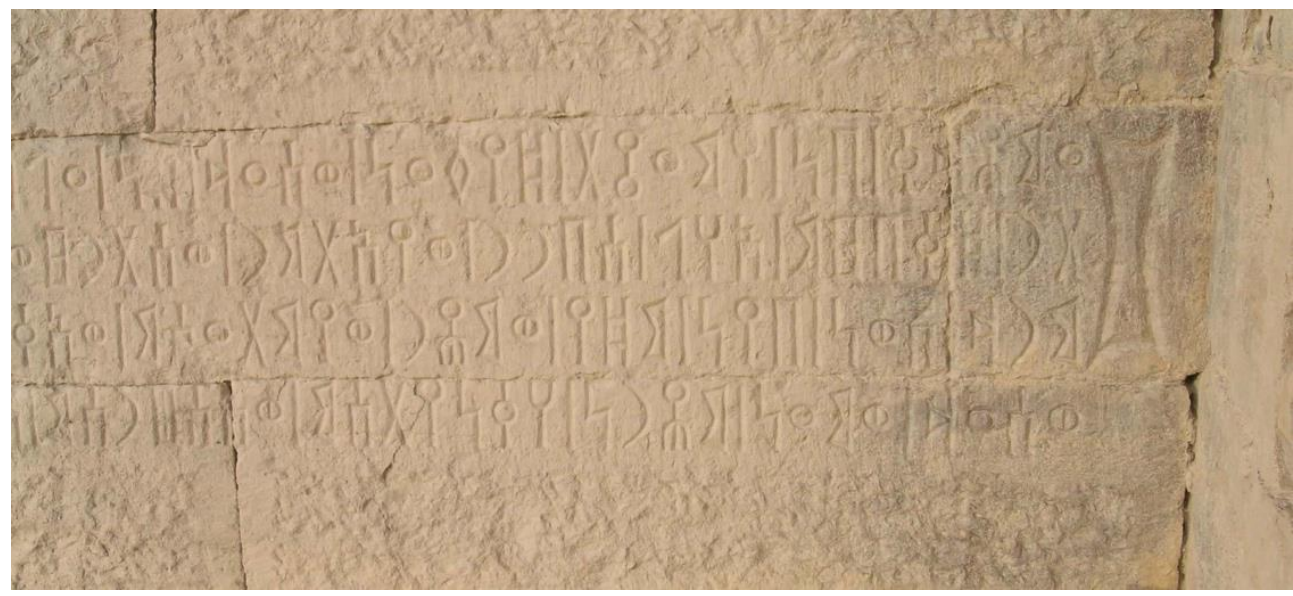

Fig. 4 - RES 3022, beginning of the right section; time of King Abiyada' Yatha'; the Persian-Minaean synchronism is at line 3 (photo by A. Agostini).

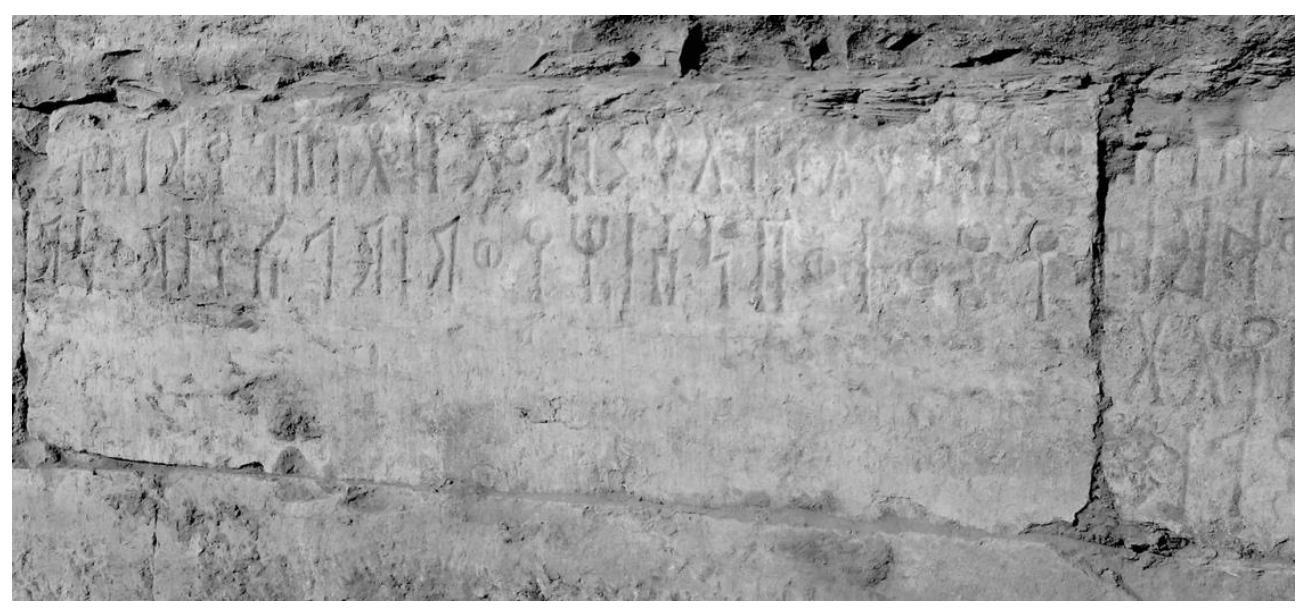

Fig. 5 - Y.03.B.R44-45.2, time of the coregency of King Abiyada' Yatha' and his son Hayyūm (CMAIRY). 